\title{
Effects of conditioner retention time during pelleting of starter feed on nutrient digestibility, ruminal fermentation, blood metabolites, and performance of Holstein female dairy calves
}

\author{
E. Soltani, ${ }^{1}$ A. A. Naserian, ${ }^{1}$ M. A. Khan, ${ }^{2}$ M. H. Ghaffari, ${ }^{3 *}$ and M. Malekkhahi ${ }^{4 *}$ \\ ${ }^{1}$ Department of Animal Science, Faculty of Agriculture, Ferdowsi University of Mashhad, Mashhad 9177948974, Iran \\ ${ }^{2}$ AgResearch Ltd., Grasslands Research Centre, Private Bag 11008, Palmerston North 4474, New Zealand \\ ${ }^{3}$ Institute of Animal Science, Physiology Unit, University of Bonn, 53115 Bonn, Germany \\ ${ }^{4}$ Dordaneh Razavi Animal and Poultry Feed Co., Mashhad, 917794883, Iran
}

\section{ABSTRACT}

This study evaluated the effects of conditioner retention time during the pelleting process of starter feed on intake, nutrient digestibility, ruminal fermentation, blood metabolites, and growth performance of dairy calves. A total of 30 Holstein female dairy calves [40 \pm $1.93 \mathrm{~kg}$ of body weight (BW)] were randomly assigned to 1 of 3 treatments: (1) pelleted starter conditioned for $0 \mathrm{~min}(\mathrm{CON}),(2)$ pelleted starter conditioned for $2 \mathrm{~min}$, and (3) pelleted starter conditioned for $4 \mathrm{~min}$. Three pelleted starter feeds had similar nutritional composition, and the starters were blended with $3 \%$ chopped wheat straw and fed to individually housed calves from d 3 to 70 of age. All calves were fed 4 $\mathrm{L} / \mathrm{d}$ of pasteurized whole milk twice daily at 0800 and $1600 \mathrm{~h}$ from d 3 to 50 of calf age, followed by $2 \mathrm{~L} / \mathrm{d}$ of morning feeding from 51 to $56 \mathrm{~d}$ of age. All calves were weaned on d 56 of age and remained in the study until d 70 of age. With the increase of conditioner retention time during pellet processing for 0,2 , and $4 \mathrm{~min}$, the gelatinized starch content of pelleted starter feed linearly increased from 14,30 , and $45 \%$, respectively. Additionally, the pellet durability and hardness also linearly increased with increasing conditioner retention time during pelleting. Feeding pelleted feed prepared using different conditioner retention time did not affect feed dry matter intake, metabolizable energy intake, weaning $\mathrm{BW}$, final $\mathrm{BW}$, or feed efficiency during the study. We observed no differences in the total-tract apparent digestibility of organic matter, neutral detergent fiber, and crude protein around weaning (d 49 to 56 of age) and after weaning (d 63 to 70 of calf cage); however, the digestibility of dry matter and starch af-

Received February 11, 2020.

Accepted April 25, 2020.

*Corresponding authors: mmalekkhahi@gmail.com and morteza1@ uni-bonn.de ter weaning was increased with increasing conditioner retention time during pelleting of starter feed. No difference was found in overall average daily gain (ADG) or growth rates of hip height, withers height, and heart girth. Ruminal volatile fatty acid profile was not affected by pelleting under different conditioner retention times. The ruminal ammonia concentration tended to be lower for calves fed the 4-min diet compared with those fed the CON diet during the postweaning period. The postweaning (d 57-70 of age) ADG was greater for calves fed the 4-min diet compared with those fed the CON diet. In conclusion, the conditioning time during the pelleting process of starter feed increased the gelatinization of starch, durability, and hardness of the pellets but did not influence feed intake, feed efficiency, and skeletal growth during the first $70 \mathrm{~d}$ of age. Increasing conditioning time during the pelleting process improved postweaning ADG; however, the final BW of calves was similar among treatments.

Key words: calf, starter, processing, growth

\section{INTRODUCTION}

Cereal grains are the primary source of energy, and starch supplied mostly by cereal grains represents a large fraction of calf starter diets (Huntington, 1997). Therefore, research on solid feeds for calves has mainly focused on nutrient composition of starter feed (Laarman et al., 2012; Berends et al., 2018), physical form of starter (Bach et al., 2007; Mirzaei et al., 2016; OmidiMirzaei et al., 2018), sources of nutrients (Khan et al., 2008; Hadam et al., 2016; Moeinoddini et al., 2017), and processing methods of grains in starter rations (Jarrah et al., 2013; Pezhveh et al., 2014). It is well established that physical form and endosperm texture of cereal grains play an important role in determining the rate and site of starch digestion in ruminants (Philippeau et al., 1999). Processing of cereal grains (e.g., grinding, flaking, and rolling) along with methods used in 
feed manufacturing (e.g., pelleting and extrusion, and texturizing) also influences the ruminal and intestinal digestibility of feed and starch (Firkins et al., 2001; Hu et al., 2018; Gelsinger et al., 2019) and therefore health (Khafipour et al., 2009; Gressley et al., 2011) and performance (Khan et al., 2008; Gressley et al., 2011; $\mathrm{Hu}$ et al., 2018) of both young and adult cattle. The effects of processing of different cereal grains in starter rations on the performance of calves have been studied (Lesmeister and Heinrichs, 2004; Bateman et al., 2009; Jarrah et al., 2013); however, information about the effects of pellet processing on performance of dairy calves is insufficient. Porter et al. (2007) suggested greater ADG, starter intake, and earlier initiation of rumination in neonatal calves fed a coarse meal diet versus a fine particle diet that had been pelleted.

Pelleting has been widely used for feed processing in the animal feed industry and proved advantageous in improving palatability, reducing ingredient segregation and wastage of starter feeds. Calf starters are either completely pelleted or pellets are mixed with processed grains and forages to form texturized calf starters (Khan et al., 2016). Pelleting increases the percentage of gelatinized starch or the number of starch molecules that have swollen during the heating process are irreversibly dissolved to allow for more hydrogen bonding sites (Waigh et al., 2000; Crochet et al., 2005) and therefore could influence fermentation and digestion of feeds (Abdollahi et al., 2012). For pelleting, the dry feed ingredients are conditioned in a process where saturated steam is injected into the feed while being mixed in a paddle mixer (Svihus et al., 2005). Immediately following the conditioning process, feed enters the pellet press where it is forced through cylindrical holes in a die and is shaped into the pellets (Svihus et al., 2004). In conventional conditioners, feed mixture is heated at 75 to $87^{\circ} \mathrm{C}$ for a maximum of 15 to $20 \mathrm{~s}$ (Fahrenholz, 2015) and this processing increased the content of gelatinized starch (Abdollahi et al., 2012). However, in the new generation (super conditioner), a meal is inserted into a separate conditioner with a slope angle for improving the filling and the residence time. The higher retention time capacity, temperature controlling, and improved mixing of starch may allow the moisture and heat to penetrate more smoothly and deeply into the feed ingredients, which can provide benefits such as more starch gelatinization and digestibility (Abdollahi et al., 2012).

Many studies have recently investigated the effects of a pelleted starter (Bateman et al., 2009; Senevirathne et al., 2017; Aragona et al., 2020) on starter feed intake, growth performance, and ruminal fermentation of dairy calves. However, it is important to note that the scien- tific research mentioned above did not study pelleting processing, and more information is needed to evaluate the effects of conditioning time of mixed starter before the pelleting process on calf performance.

Thus, the objective of this study was to evaluate how pelleting conditioner retention time $(0,2$, and $4 \mathrm{~min})$ during the pelleting process of the starter feed influences intake, apparent nutrient digestibility, ruminal fermentation, blood metabolites, and growth performance of dairy calves during the pre- and postweaning periods. We hypothesized that increasing conditioning time of the pelleted starter would promote pellet quality and may further improve calf performance.

\section{MATERIALS AND METHODS}

The present study was carried out at the Dairy Teaching and Research Facility, Ferdowsi University of Mashhad, Mashhad, Iran. All the experimental procedures and animal manipulations were approved by the Animal Care and Use Committee of Ferdowsi University of Mashhad (IACUC \#A20175) outlined by the Iranian Council of Animal Care (1995).

\section{Experimental Treatments, Feeding, and Measurements}

A total of 30 Holstein female dairy calves $(40 \pm 1.93$ $\mathrm{kg}$ of BW) were born between March 1 to 20, 2018, and were separated from their dams at birth, weighed, and transferred to individual pens $(1.2 \times 2.5 \mathrm{~m})$ bedded with sawdust that was replaced every 24 or $48 \mathrm{~h}$ as needed during the study. A pre-study power analysis for sample size estimation was performed (Morris, 1999; Hintze, 2008) for the primary response variables, including feed intake, BW, and ADG based on previously reported values (Abdelsamei et al., 2005; DeVries and von Keyserlingk, 2009; Miller-Cushon and DeVries, 2011). From the power test analysis, using $\alpha=0.05$ and power $=$ 0.80 , the projected sample size was approximately 30 calves in total for DMI, ADG, and hip height. Calves consumed $2.0 \mathrm{~L}$ of colostrum within $1.5 \mathrm{~h}$ after birth and another $2 \mathrm{~L} 12 \mathrm{~h}$ later. From the second feeding time until d 2 of life, all calves received colostrum and transition milk. Blood samples were taken by venipuncture from the jugular vein at $24 \mathrm{~h}$ after the first colostrum intake and serum total protein was determined as an indicator of passive transfer of immunity using a Rechert AR200 digital handheld refractometer (Reichert Inc., Depew, NY). Only calves having a serum protein level $>6 \mathrm{~g} / \mathrm{dL}$ were included in the study. A total of 30 calves ( $3 \mathrm{~d}$ old $)$ were enrolled in the study and were fed $4 \mathrm{~L} / \mathrm{d}$ of pasteurized whole milk (containing $3.22 \pm$ 
$0.11 \%$ fat, $2.96 \pm 0.07 \% \mathrm{CP}, 4.92 \pm 0.05 \%$ lactose, and $11.7 \pm 0.15 \%$ TS $)$ in buckets twice daily at 0800 and $1600 \mathrm{~h}$ from d 3 to 50 , followed by morning feeding (2 $\mathrm{L} / \mathrm{d}$ ) from 51 to $56 \mathrm{~d}$ of age. Samples of milk were taken from a bulk farm tank and were pasteurized by heating for $30 \mathrm{~min}$ at $62.5^{\circ} \mathrm{C}$ (Pazoki et al., 2017). Representative samples of milk $(\mathrm{n}=30)$ were taken from both the morning and evening meals twice per week, preserved with potassium dichromate, stored at $4^{\circ} \mathrm{C}$, and then analyzed for concentration of fat, protein, and lactose by Milko-Scan (605, Foss Electric, Hillerød, Denmark). All calves were weaned on d 56 of age and remained in the study until d 70 of age.

On d 3 of age, calves were randomly assigned to 1 of 3 calf starter treatments: (1) pelleted starter conditioned for 0 min (negative control, CON), (2) pelleted starter conditioned for $2 \mathrm{~min}$, and (3) pelleted starter conditioned for $4 \mathrm{~min}$. Calves had unlimited access to fresh drinking water and were fed starter feed diets (formulated to meet their nutrient requirements; NRC, 2001) to provide at least $10 \%$ refusals. All pelleted starters were uniformly mixed with $3 \%$ chopped straw and offered as a TMR. The ingredient and nutrient compositions of the pelleted diets are presented in Table 1. The pelleted starters in 3 treatments were produced from the same batch of ingredients, and all experimental starter feeds had similar ingredients and nutritional and chemical composition. All diets were manufactured at the Dordaneh Razavi Feed Mill Co. (Mashhad, Iran), which was equipped with a new generation of conditioners (super conditioner). Each diet was mixed in a double-shaft paddle mixer (Venver, Vilanova del Camí, Spain) and then divided into 3 equal batches. The first batch was not conditioned but was pelleted in dry mode $(\mathrm{CON})$, whereas the second and third batches were passed through a super conditioner (Stolz, Paris, France) providing $80^{\circ} \mathrm{C}$ temperature of feed and steam mixture for 2 and 4 min, respectively, and were then pelleted through a $4-\mathrm{mm}$ die using a pellet mill (model 660.228, Münch Edelstahl GmbH, Hilden, Germany). The conditioning temperature was measured at the outlet (close to the exit point) of the conditioner before the mash feed entered the die. Diets were run in sequence with no change in the feeder rate, die rotation speed, or number of knives.

\section{Sample Collection and Analysis}

Calf health was checked daily by a veterinarian blinded to the treatments, and sick calves were treated by a veterinarian accordingly. Feces were scored daily in the morning using a 1 to 5 scale (score 1 being normal and 5 being watery) while calves were in individual pens (Kertz and Chester-Jones, 2004).
Representative diet samples $(\mathrm{n}=3$ for each feed) were collected for the determination of gelatinized starch, pellet durability, and pellet hardness. All representative samples of diets were collected to calculate the pellet durability index (PDI) and hardness. The PDI was measured using a Holmen Pellet Tester (New Holmen NHP100 Portable Pellet Durability Tester, TekPro Ltd., Willow Park, North Walsham, Norfolk, UK) as described by Abdollahi et al. (2012). The hardness tester machine (Amandus Kahl, GmbH \& Co. KG, Hamburg, Germany) was used to determine pellet hardness, according to the method described by Svihus et al. (2004). Eight representative samples of starter were collected from each treatment throughout the experiment and were used for particle size fraction distribution. The particle size of 3 experimental diets was measured by in duplicate dry sieving using an automatic vibratory sieve shaker (model 120, Techno Khak, Khavaran, Tehran, Iran) with 4.75-, 2.36-, 1.18, 0.6-, 0.3-, and 0.15-mm diameter screens (Table 1). Precisely $100 \mathrm{~g}$ of sample was placed on the top screen and the stack of sieves was shaken until the distribution of materials did not change (approximately 10 min). Geometric mean particle size was calculated as described by the American Society of Agricultural Engineers (ASAE, 1983).

Feed (milk and starter) offered and refused was recorded daily for each calf to determine DMI. Body weights were recorded at the start and then every 2 wk throughout the experiment using an electronic scale (model EES-500, Ettehad Inc., Isfahan, Iran), which was calibrated by the manufacturer's agent before initiation of the study and every month thereafter. Average daily gain $(\mathrm{kg}$ of $\mathrm{BW} / \mathrm{d})$ was calculated as the difference between BW taken every $14 \mathrm{~d}$ apart divided by 14 . Feed efficiency was computed as g of ADG $/ \mathrm{kg}$ of total DMI (liquid feed DMI + starter feed DMI). A sample of the feed ( $\mathrm{n}=10$, a sample per week) was taken throughout the study for DM and chemical analyses. Three fecal grab samples per calf were taken at 0600, 1400 , and $2200 \mathrm{~h}$ to account for 8-h intervals from d 49 to 56 and when calves weaned from d 63 to 70 . To do this, all 30 calves were rectally stimulated with sterile gloves to facilitate the collection of fecal samples. Individual calf fecal samples were composited (equal amount on a weight basis) into one sample per calf frozen daily, combined on an equal wet weight basis, and subsampled for analyses.

Apparent total-tract digestibility of nutrient was estimated by quantifying acid insoluble ash as an internal marker in the feed (corrected for refusals) and fecal samples according to Van Keulen and Young (1977) using a modification of the $2 \mathrm{~N} \mathrm{HCl}$ procedures. Briefly, 5 -g samples of feed or feces were dried $(2 \mathrm{~h})$ in a forced- 
Table 1. Ingredients, chemical composition, and particle size distribution of the experimental starter feeds

\begin{tabular}{|c|c|c|c|}
\hline \multirow[b]{2}{*}{ Item } & \multicolumn{3}{|c|}{ Treatment $^{1}$} \\
\hline & $\mathrm{CON}$ & $2 \min$ & $4 \mathrm{~min}$ \\
\hline \multicolumn{4}{|l|}{ Ingredient (\% of DM) } \\
\hline Chopped wheat straw & 3.00 & 3.00 & 3.00 \\
\hline Corn grain & 44.65 & 44.65 & 44.65 \\
\hline Barley grain & 14.55 & 14.55 & 14.55 \\
\hline Soybean meal, $45 \% \mathrm{CP}$ & 28.65 & 28.65 & 28.65 \\
\hline Beet pulp & 2.91 & 2.91 & 2.91 \\
\hline Wheat bran & 3.88 & 3.88 & 3.88 \\
\hline Vitamin and mineral mix $^{2}$ & 1.0 & 1.0 & 1.0 \\
\hline Calcium carbonate & 0.97 & 0.97 & 0.97 \\
\hline Dicalcium phosphate & 0.195 & 0.195 & 0.195 \\
\hline Salt & 0.195 & 0.195 & 0.195 \\
\hline \multicolumn{4}{|l|}{ Chemical composition } \\
\hline $\mathrm{ME}^{3}(\mathrm{Mcal} / \mathrm{kg})$ & 3.02 & 3.04 & 3.06 \\
\hline $\mathrm{NE}_{\mathrm{G}}{ }^{3}(\mathrm{Mcal} / \mathrm{kg})$ & 1.39 & 1.40 & 1.42 \\
\hline $\mathrm{DM}(\mathrm{g} / \mathrm{kg}$ of $\mathrm{DM})$ & 928 & 913 & 910 \\
\hline $\mathrm{OM}(\mathrm{g} / \mathrm{kg}$ of $\mathrm{DM})$ & 940 & 945 & 947 \\
\hline $\mathrm{CP}(\mathrm{g} / \mathrm{kg}$ of $\mathrm{DM})$ & 205 & 205 & 204 \\
\hline Starch (g/kg of DM) & 402 & 404 & 403 \\
\hline$\%$ of gelatinized starch & 14 & 30 & 45 \\
\hline Fat $(\mathrm{g} / \mathrm{kg}$ of $\mathrm{DM})$ & 29.3 & 29.1 & 29.3 \\
\hline $\mathrm{NDF}(\mathrm{g} / \mathrm{kg}$ of DM $)$ & 160 & 160 & 159 \\
\hline $\mathrm{ADF}(\mathrm{g} / \mathrm{kg}$ of $\mathrm{DM})$ & 70 & 70 & 69 \\
\hline $\mathrm{NFC}^{4}(\mathrm{~g} / \mathrm{kg}$ of DM) & 543 & 549 & 552 \\
\hline \multicolumn{4}{|l|}{$\begin{array}{l}\text { Particles retained on the sieve } \\
(\mathrm{g} / \mathrm{kg}, \text { mean } \pm \mathrm{SD})\end{array}$} \\
\hline $4.75 \mathrm{~mm}$ & $0.31 \pm 0.05$ & $0.43 \pm 0.05$ & $0.36 \pm 0.03$ \\
\hline $2.36 \mathrm{~mm}$ & $84 \pm 0.70$ & $89 \pm 0.82$ & $89 \pm 0.7$ \\
\hline $1.18 \mathrm{~mm}$ & $5.98 \pm 0.71$ & $4.60 \pm 0.34$ & $5.85 \pm 0.36$ \\
\hline $0.6 \mathrm{~mm}$ & $4.45 \pm 0.46$ & $2.79 \pm 0.20$ & $2.75 \pm 0.11$ \\
\hline $0.3 \mathrm{~mm}$ & $2.75 \pm 0.10$ & $1.20 \pm 0.06$ & $0.52 \pm 0.07$ \\
\hline $0.15 \mathrm{~mm}$ & $1.21 \pm 0.08$ & $0.53 \pm 0.01$ & $0.10 \pm 0.04$ \\
\hline Pan & $1.12 \pm 0.08$ & $0.94 \pm 0.04$ & $0.33 \pm 0.04$ \\
\hline $\mathrm{GMPL}^{5}(\mathrm{~mm}$, mean $\pm \mathrm{SD})$ & $2.24 \pm 0.03$ & $2.45 \pm 0.02$ & $2.54 \pm 0.02$ \\
\hline
\end{tabular}

${ }^{1}$ Treatment $=\mathrm{CON}$ : starter feed without thermal processing (negative control); 2 min: starter feed conditioned for $2 \mathrm{~min}$; $4 \mathrm{~min}$ : starter feed conditioned for $4 \mathrm{~min}$.

${ }^{2}$ Contained per kilogram of supplement: 250,000 IU of vitamin A, 50,000 IU of vitamin D, 1,500 IU of vitamin E, $2.25 \mathrm{~g}$ of Mn, $120 \mathrm{~g}$ of Ca, $7.7 \mathrm{~g}$ of Zn, $20 \mathrm{~g}$ of P, $20.5 \mathrm{~g}$ of Mg, $186 \mathrm{~g}$ of Na, $1.25 \mathrm{~g}$ of Fe, $3 \mathrm{~g}$ of S, $14 \mathrm{mg}$ of $\mathrm{Co}, 1.25 \mathrm{~g}$ of $\mathrm{Cu}, 56 \mathrm{mg}$ of $\mathrm{I}$, and $30 \mathrm{mg}$ of Se.

${ }^{3}$ Calculated from NRC (2001).

${ }^{4}$ Nonfiber carbohydrate was calculated as DM - (NDF + CP + ether extract + ash) (NRC, 2001).

${ }^{5} \mathrm{GMPL}=$ geometric mean particle size; calculated as described by the American Society of Agricultural Engineers (ASAE, 1983).

air oven $\left(135^{\circ} \mathrm{C}\right)$ and then ashed overnight at $450^{\circ} \mathrm{C}$. The ash was mixed with $100 \mathrm{~mL}$ of $2 \mathrm{~N} \mathrm{HCl}$ and the mixture was then boiled for $5 \mathrm{~min}$. The hot hydrolysate was filtered and washed with hot distilled water (85 to $100^{\circ} \mathrm{C}$ ). The ash and filter paper were transferred into the crucible and ashed overnight at $450^{\circ} \mathrm{C}$. The crucible and content were cooled and weighed.

For other chemical analyses, feed samples were ovendried at $55^{\circ} \mathrm{C}$ for $48 \mathrm{~h}$ and fecal samples were dried at $60^{\circ} \mathrm{C}$ for $72 \mathrm{~h}$ and stored at $-20^{\circ} \mathrm{C}$. Feed, refusal, and fecal samples were mixed thoroughly and ground to pass a 1-mm screen in a Wiley mill (Ogawa Seiki Co. Ltd., Tokyo, Japan) and subsequently analyzed for CP (AOAC, 1990; method 988.05), NDF without the use of sodium sulfite and with the inclusion of $\alpha$-amylase (Van Soest et al., 1991), ADF (AOAC, 1990; method 973.18), and ash (AOAC, 1990; method 942.05). The NFC component was computed as $100-(\mathrm{CP}+\mathrm{NDF}+$ ether extract + ash) (NRC, 2001).

Total starch content was determined using Megazyme Total Starch Assay Kit (Megazyme International Ireland Ltd., Bray, County Wicklow, Ireland) following the approved American Association of Cereal Chemists method (76-13.01; AACC International 1999). Starch gelatinization was determined according to the approved AACC method (76-31.01; AACC International 2014) by using a Megazyme Starch Damage Assay Kit (product code: K-SDAM). 
Body measurements including body length (distance between the point of shoulder and rump), body girth (circumference of barrel at the last rib), withers height (distance from base of the front feet to the withers), heart girth (circumference of the chest), hip height (distance from base of the rear feet to hook bones), and hip width (distance between the points of hook bones) of the calves were recorded on d 3 of age, weaning (d 56 of age; weaning), and at $\mathrm{d} 70$ of age (end of the study) according to the method described by Khan et al. (2007).

Fecal scores were recorded daily based on a 1 to 5 system $(1=$ normal; $2=$ soft to loose; $3=$ loose to watery; 4 = watery, mucous, and slightly bloody; and $5=$ watery, mucous, and bloody) while calves were in individual pens (Kertz and Chester-Jones, 2004).

Ruminal fluid samples were obtained using a stomach tube $4 \mathrm{~h}$ after the morning feeding on d 35 and 70 of the study. Ruminal contents were squeezed through 4 layers of cheesecloth. To avoid saliva contamination, the first $50 \mathrm{~mL}$ of gathered ruminal fluid was discarded. Then ruminal samples were also taken for the analysis of $\mathrm{NH}_{3}-\mathrm{N}(5 \mathrm{~mL}$ mixed with $5 \mathrm{~mL} 0.2 \mathrm{~N} \mathrm{HCl})$ and VFA (10 mL of ruminal fluid was acidified with $3 \mathrm{~mL}$ of $25 \%$ metaphosphoric acid) and stored at $-20^{\circ} \mathrm{C}$ until analysis. Ruminal samples were analyzed for VFA by GC $(0.25 \times 0.32 \mathrm{~m}, 0.3 \mu \mathrm{m}$ i.d. fused-silica capillary, model no. CP-9002, Vulcanusweg 259 a.m., Chrompack, Delft, the Netherlands) as described by Bal et al. (2000).

Blood samples were obtained on d 35 and 70 of the age by venipuncture of the jugular vein into an evacuated tube (Becton Dickinson, Franklin Lakes, NJ) containing clot activator $3 \mathrm{~h}$ after the morning feeding and immediately placed on ice. Tubes were centrifuged at $2,000 \times g$ for $15 \mathrm{~min}$ at $4^{\circ} \mathrm{C}$ to separate the serum, which was then stored at $-20^{\circ} \mathrm{C}$ for subsequent analysis. Plasma glucose (catalog numbers: 1-500-017) and urea N (catalog numbers: 1-400-029) concentrations were analyzed using commercial kits (Pars Azmoon Kit, Pars Azmoon, Tehran, Iran) by an automated analyzer (Technicon-RA 1000 Auto analyzer, DRG Instruments GmbH, Marburg, Germany). Concentrations of IGF-1 was determined by an automated biochemistry Analyzer (model GF-D200, Caihong Co., Shandong, China). Plasma insulin concentration was measured with an RIA kit (PI-12K, Millipore Oy, Espoo, Finland) as previously used by Vicari et al. (2008). Intra- and interassay CV for insulin were $5.4 \%$ and $6.3 \%$, respectively.

\section{Statistical Analysis}

Data were subjected to ANOVA using the MIXED procedure of SAS (PROC MIXED, SAS 9.4, SAS Institute Inc., Cary, NC) with time as repeated measures for starter feed intake, DMI, ME intake, BW, ADG, and feed efficiency during the preweaning (d 3 to 56 of age), postweaning (d 57 to 70 of age), and overall (d 3 to 70 of age) periods. The model consisted of treatment, time (sampling date), and treatment $\times$ time interaction as the fixed effects, and calf as the random effect. Before analyses, all data were screened for normality using the UNIVARIATE procedure of SAS. Three variance-covariance structures (auto-regressive type 1, compound symmetry, and Toeplitz) were tested and the covariance structure that minimized the Schwarz's Bayesian information criterion was chosen. Initial BW was used as a covariate for final weight. Skeletal growth (d 3, 56, and 70), ruminal fermentation, digestibility, and blood metabolite (d 56 and 70) data were analyzed using the above model without the effect of time. The TukeyKramer adjustment was applied to account for multiple comparisons. The threshold of significance was set at $P$ $\leq 0.05$; trends were declared at $0.05<P \leq 0.10$.

\section{RESULTS}

\section{Chemical Composition, Pellet Quality of the Starter, and Particle Size Distributions}

The ingredients, chemical composition, and the particle size distributions of starter diets are shown in Table 1. The pelleted starters were formulated to obtain $20 \% \mathrm{CP}$ and $40 \%$ starch. The ingredients used to formulate calf starter was similar and therefore all experimental diets had similar nutrient composition. A small difference was observed in DM and NFC content between pellets, which was not anticipated based on individual feed nutrient composition. The pellet quality parameters of experimental feeds are presented in Table 1. The CON starter diet had a smaller amount of particle retention on the second screens (i.e., $2.36 \mathrm{~mm}$ ) compared with other diets, resulting in the lowest geometric mean particle length of $2.24 \mathrm{~mm}$. It was found that increasing conditioning time contributed to the increase in durability $(P<0.01)$ and hardness $(P<0.01)$ of the pelleted starter feed (Table 2). Additionally, with the increase of conditioning time $(0,2$, and $4 \mathrm{~min})$ the gelatinized starch content of pellets linearly increased from $14 \%$ to $30 \%$ and $45 \%(P<0.01)$, respectively.

\section{Intake and Growth Performance}

Pelleting under different conditioner retention time did not affect starter fecal scores, feed intake $(\mathrm{kg} / \mathrm{d})$, total (milk and solid feed) DMI $(\mathrm{kg} / \mathrm{d})$, total ME intake (Mcal/d), weaning BW and final BW, and feed efficiency during the preweaning, postweaning, and 
Table 2. Effects of pelleting conditioner retention time on pellet durability index (PDI), hardness, and starch gelatinization of starter feed

\begin{tabular}{lcccrc}
\hline & \multicolumn{3}{c}{ Treatment $^{1}$} & & \\
\cline { 2 - 4 } Item & CON & 2 min & 4 min & SEM & $P$-value \\
\hline PDI $^{2}(\%)$ & $32.65^{\mathrm{b}}$ & $78.43^{\mathrm{a}}$ & $82.84^{\mathrm{a}}$ & 0.52 & 0.01 \\
Hardness $^{3}(\mathrm{~kg})$ & $2.30^{\mathrm{b}}$ & $4.50^{\mathrm{a}}$ & $4.26^{\mathrm{a}}$ & 0.30 & 0.01 \\
Gelatinized starch (\% of starch) & $14^{\mathrm{b}}$ & $30^{\mathrm{a}}$ & $45^{\mathrm{a}}$ & 0.20 & 0.01 \\
\hline
\end{tabular}

$\overline{\mathrm{a}, \mathrm{b}}$ Means within a row with different superscripts are significantly different $(P<0.05)$.

${ }^{1}$ Treatment $=\mathrm{CON}$ : starter feed without thermal processing (negative control); 2 min: starter feed conditioned for $2 \mathrm{~min}$; 4 min: starter feed conditioned for $4 \mathrm{~min}$.

${ }^{2} \mathrm{PDI}=$ (weight of pellets before tumbling) $/$ (weight of pellets after tumbling $) \times 100 \%$.

${ }^{3}$ Hardness $=$ pressure applied in kilograms.

Table 3. Effects of pelleting conditioner retention time on feed intake, BW, ADG, and feed efficiency of dairy calves ( $\mathrm{n}=10$ per group)

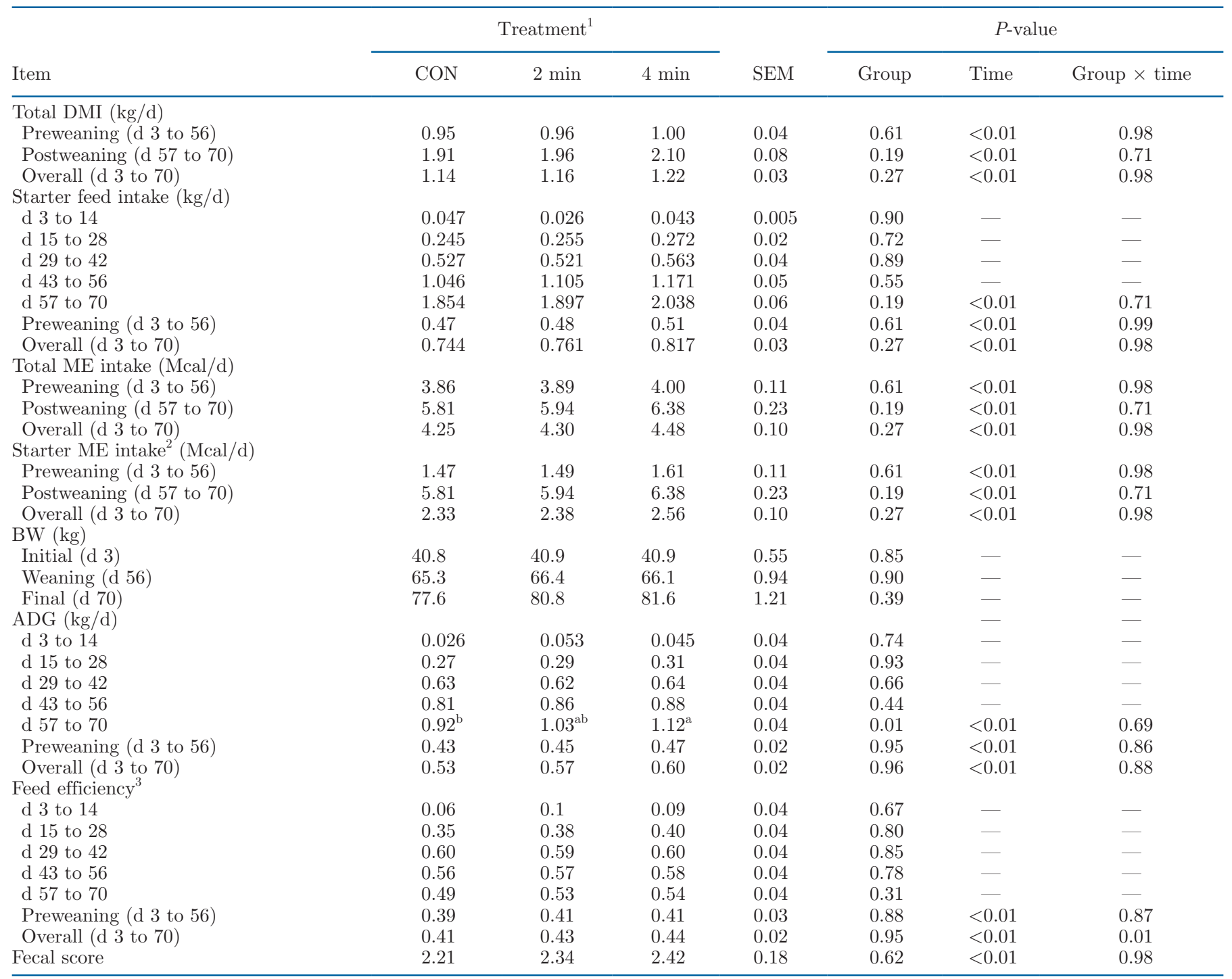

${ }_{\mathrm{a}, \mathrm{b}}$ Means with different superscripts within a row indicate a $P$-value $\leq 0.05$.

${ }^{1}$ Treatment $=\mathrm{CON}$ : starter feed without thermal processing (negative control); 2 min: starter feed conditioned for 2 min; 4 min: starter feed conditioned for $4 \mathrm{~min}$.

${ }^{2}$ Total ME was calculated from intakes of milk and starter.

${ }^{3}$ Feed efficiency $=$ ADG $/$ total DMI. 
Table 4. Effects of pelleting conditioner retention time on skeletal growth of dairy calves ( $\mathrm{n}=10$ per group)

\begin{tabular}{|c|c|c|c|c|c|}
\hline \multirow[b]{2}{*}{ Item } & \multicolumn{3}{|c|}{ Treatment $^{1}$} & \multirow[b]{2}{*}{ SEM } & \multirow[b]{2}{*}{$P$-value } \\
\hline & $\mathrm{CON}$ & $2 \min$ & $4 \min$ & & \\
\hline \multicolumn{6}{|l|}{ Body length (cm) } \\
\hline Initial (d 3) & 42.4 & 42.6 & 42.5 & 0.65 & 0.75 \\
\hline Weaning (d 56) & 51.10 & 51.65 & 51.72 & 0.56 & 0.58 \\
\hline Final (d 70) & 53.93 & 54.46 & 54.53 & 0.71 & 0.36 \\
\hline \multicolumn{6}{|l|}{ Heart girth $(\mathrm{cm})$} \\
\hline Initial (d 3) & 79.7 & 80.1 & 79.9 & 0.87 & 0.57 \\
\hline Weaning (d 56) & 94.9 & 95.6 & 96.8 & 0.92 & 0.39 \\
\hline Final (d 70) & 100.4 & 100.8 & 101.1 & 1.29 & 0.22 \\
\hline \multicolumn{6}{|l|}{ Body girth $(\mathrm{cm})$} \\
\hline Initial (d 3) & 81.9 & 81.6 & 82 & 1.02 & 0.66 \\
\hline Weaning (d 56) & 108.2 & 109.7 & 112.3 & 1.61 & 0.58 \\
\hline Final (d 70) & 115.9 & 117.4 & 117.7 & 1.79 & 0.31 \\
\hline \multicolumn{6}{|c|}{ Withers height $(\mathrm{cm})$} \\
\hline Initial (d 3) & 76.5 & 77.1 & 76.8 & 0.57 & 0.82 \\
\hline Weaning (d 56) & 84.66 & 85.28 & 85.53 & 0.69 & 0.71 \\
\hline Final (d 70) & 87.60 & 88.37 & 88.91 & 0.74 & 0.44 \\
\hline \multicolumn{6}{|l|}{ Hip height $(\mathrm{cm})$} \\
\hline Initial (d 3) & 79.7 & 80.1 & 80.2 & 0.67 & 0.59 \\
\hline Weaning (d 56) & 88.92 & 89.74 & 89.88 & 0.96 & 0.73 \\
\hline Final (d 70) & 93.84 & 94.26 & 94.30 & 1.03 & 0.35 \\
\hline \multicolumn{6}{|l|}{ Hip width $(\mathrm{cm})$} \\
\hline Initial (d 3) & 18.8 & 18.7 & 19.1 & 0.44 & 0.52 \\
\hline Weaning (d 56) & 21.4 & 21.5 & 21.7 & 0.54 & 0.43 \\
\hline Final (d 70) & 24.3 & 24.6 & 24.9 & 0.69 & 0.19 \\
\hline
\end{tabular}

${ }^{1}$ Treatment $=$ CON: pelleted starter conditioned for 0 min; 2 min: starter feed conditioned for 2 min; 4 min: starter feed conditioned for $4 \mathrm{~min}$.

overall periods (Table 3). There were no differences between treatments on preweaning and overall ADG, but postweaning (d 57-70 of age) ADG was greater $(P=$ 0.01 ) in calves fed the 4-min diet compared with those fed the CON diet (Table 3). Body length, heart girth, body barrel, withers height, hip height, and hip width of calves did not differ between treatments (Table 4).

\section{Nutrient Digestibility}

We observed no overall differences in the tract apparent digestibility of $\mathrm{OM}, \mathrm{NDF}$, and $\mathrm{CP}$ around weaning (d 49 to 56 of age) and after weaning (d 63 to 70 of age; Table 5). Whole-tract apparent digestibility of DM and starch around weaning was not affected by the

Table 5. Effects of pelleting conditioner retention time on apparent nutrient digestibility of dairy calves $(\mathrm{n}=$ 10 per group)

\begin{tabular}{|c|c|c|c|c|c|}
\hline \multirow{2}{*}{$\begin{array}{l}\text { Apparent total-tract nutrient } \\
\text { digestibility }(\%)\end{array}$} & \multicolumn{3}{|c|}{ Treatment ${ }^{1}$} & \multirow[b]{2}{*}{ SEM } & \multirow[b]{2}{*}{$P$-value } \\
\hline & $\mathrm{CON}$ & $2 \min$ & $4 \min$ & & \\
\hline \multicolumn{6}{|l|}{$\overline{\mathrm{DM}}$} \\
\hline d 49 to 56 & 73.87 & 74.25 & 74.61 & 0.69 & 0.75 \\
\hline d 63 to 70 & $76.44^{\mathrm{b}}$ & $78.83^{\mathrm{ab}}$ & $79.59^{\mathrm{a}}$ & 0.83 & 0.03 \\
\hline \multicolumn{6}{|l|}{$\mathrm{OM}$} \\
\hline d 49 to 56 & 74.59 & 75.12 & 75.83 & 0.78 & 0.54 \\
\hline d 63 to 70 & 77.82 & 79.92 & 80.43 & 0.9 & 0.11 \\
\hline \multicolumn{6}{|l|}{$\mathrm{CP}$} \\
\hline d 49 to 56 & 63.56 & 64.22 & 65.08 & 0.91 & 0.51 \\
\hline d 63 to 70 & 68.32 & 70.65 & 70.16 & 1.03 & 0.26 \\
\hline \multicolumn{6}{|l|}{ NDF } \\
\hline d 49 to 56 & 50.72 & 51.66 & 52.35 & 1.05 & 0.55 \\
\hline d 63 to 70 & 62.94 & 64.83 & 66.72 & 1.25 & 0.12 \\
\hline \multicolumn{6}{|l|}{ Starch } \\
\hline d 49 to 56 & 94.56 & 95.91 & 96.32 & 0.61 & 0.13 \\
\hline d 63 to 70 & $94.71^{\mathrm{b}}$ & $96.63^{\mathrm{ab}}$ & $97.4^{\mathrm{a}}$ & 0.68 & 0.03 \\
\hline
\end{tabular}

${ }_{\mathrm{a}, \mathrm{b}}$ Means with different superscripts within a row indicate a $P$-value $\leq 0.05$.

${ }^{1}$ Treatment $=\mathrm{CON}$ : pelleted starter conditioned for $0 \mathrm{~min} ; 2 \mathrm{~min}$ : starter feed conditioned for $2 \mathrm{~min} ; 4 \mathrm{~min}$ : starter feed conditioned for $4 \mathrm{~min}$. 
Table 6. Effects of pelleting conditioner retention time on ruminal fermentation in dairy calves $(\mathrm{n}=10$ per group)

\begin{tabular}{|c|c|c|c|c|c|}
\hline \multirow[b]{2}{*}{ Item } & \multicolumn{3}{|c|}{ Treatment $^{1}$} & \multirow[b]{2}{*}{ SEM } & \multirow[b]{2}{*}{$P$-value } \\
\hline & $\mathrm{CON}$ & $2 \min$ & $4 \mathrm{~min}$ & & \\
\hline \multicolumn{6}{|c|}{ Ruminal ammonia (mg/dL) } \\
\hline Weaning (d 56) & 6.23 & 5.78 & 5.39 & 0.29 & 0.16 \\
\hline Final (d 70) & 6.76 & 5.81 & 5.44 & 0.35 & 0.07 \\
\hline \multicolumn{6}{|c|}{ Total VFA (mmol/L) } \\
\hline Weaning (d 56) & 93.37 & 95.56 & 99.28 & 3.22 & 0.49 \\
\hline Final (d 70) & 96.12 & 103.72 & 108.30 & 5.18 & 0.12 \\
\hline \multicolumn{6}{|c|}{ Individual VFA (mol/100 mol) } \\
\hline \multicolumn{6}{|c|}{ Acetate } \\
\hline Weaning (d 56) & 50.85 & 50.28 & 50.07 & 0.39 & 0.76 \\
\hline Final (d 70) & 51.04 & 50.09 & 48.53 & 0.84 & 0.38 \\
\hline \multicolumn{6}{|l|}{ Propionate } \\
\hline Weaning (d 56) & 33.53 & 34.23 & 34.56 & 0.52 & 0.62 \\
\hline Final (d 70) & 34.14 & 34.92 & 36.49 & 0.78 & 0.15 \\
\hline \multicolumn{6}{|l|}{ Butyrate } \\
\hline Weaning (d 56) & 11.99 & 11.79 & 12.05 & 0.64 & 0.59 \\
\hline Final (d 70) & 11.67 & 11.71 & 11.86 & 0.76 & 0.61 \\
\hline \multicolumn{6}{|l|}{ Valerate } \\
\hline Weaning (d 56) & 3.62 & 3.67 & 3.3 & 0.37 & 0.48 \\
\hline Final (d 70) & 3.12 & 3.26 & 3.1 & 0.26 & 0.36 \\
\hline \multicolumn{6}{|c|}{ Acetate:propionate ratio } \\
\hline Weaning (d 56) & 1.52 & 1.47 & 1.45 & 0.09 & 0.24 \\
\hline Final (d 70) & 1.50 & 1.43 & 1.33 & 0.12 & 0.30 \\
\hline
\end{tabular}

${ }^{1}$ Treatment $=\mathrm{CON}$ : pelleted starter conditioned for $0 \mathrm{~min} ; 2 \mathrm{~min}$ : starter feed conditioned for $2 \mathrm{~min} ; 4 \mathrm{~min}$ : starter feed conditioned for $4 \mathrm{~min}$.

treatments; however, the digestibility of DM and starch after weaning was increased $(P=0.03)$ with increasing pelleting conditioner retention time of starter feed (Table 5).

\section{Ruminal Fermentation and Blood Parameters}

Pelleting under different conditioner retention time did not affect the total ruminal VFA concentration, the molar proportion of ruminal acetate, propionate, butyrate, and acetate to propionate ratio (Table 6).
The ruminal ammonia concentration tended to be lower (linearly, $P=0.07$ ) with increasing conditioner time. The plasma concentrations of glucose, insulin, BUN, and IGF-1 on d 56 and 70 of age were not influenced by the conditioning time of the pelleting process (Table 7 ).

\section{DISCUSSION}

Pellet durability and hardness are important indicators of the quality of pelleted feed. Our results showed that increasing the conditioning time of the pellet-

Table 7. Effects of pelleting conditioner retention time on blood metabolites of dairy calves $(\mathrm{n}=10$ per group)

\begin{tabular}{|c|c|c|c|c|c|}
\hline \multirow[b]{2}{*}{ Item } & \multicolumn{3}{|c|}{ Treatment $^{1}$} & \multirow[b]{2}{*}{ SEM } & \multirow[b]{2}{*}{$P$-value } \\
\hline & $\mathrm{CON}$ & $2 \min$ & $4 \min$ & & \\
\hline \multicolumn{6}{|l|}{ Glucose $(\mathrm{mg} / \mathrm{dL})$} \\
\hline Weaning (d 56) & 101.2 & 106.8 & 108.2 & 6.45 & 0.73 \\
\hline Final (d 70) & 97.4 & 97.2 & 97.4 & 4.20 & 0.95 \\
\hline \multicolumn{6}{|l|}{ Insulin $(\mu M / \mathrm{mL})$} \\
\hline Weaning (d 56) & 8.92 & 9.62 & 10 & 0.70 & 0.56 \\
\hline Final (d 70) & 8.90 & 8.80 & 9.16 & 0.42 & 0.83 \\
\hline \multicolumn{6}{|l|}{ BUN (mg/dL) } \\
\hline Weaning (d 56) & 13.34 & 12.84 & 11.3 & 0.64 & 0.13 \\
\hline Final (d 70) & 12.9 & 12.34 & 12.32 & 0.39 & 0.50 \\
\hline \multicolumn{6}{|l|}{ IGF-1 (ng/mL) } \\
\hline Weaning (d 56) & 95.2 & 98.5 & 100.9 & 3.61 & 0.25 \\
\hline Final (d 70) & 115.7 & 119.1 & 123.8 & 2.89 & 0.13 \\
\hline
\end{tabular}

${ }^{1}$ Treatment $=\mathrm{CON}$ : pelleted starter conditioned for $0 \mathrm{~min} ; 2 \mathrm{~min}$ : starter feed conditioned for $2 \mathrm{~min} ; 4 \mathrm{~min}$ : starter feed conditioned for $4 \mathrm{~min}$. 
ing process has enhanced both PDI and hardness of pelleted starter feeds. In the feed processing, the low hardness of the pellets is not desirable because storage and transportation could negatively affect the pellet structure, whereas excessive hardness could cause wear and tear of the granulator during processing. Therefore, according to our results, it seems that the conditioning time of 2 and $4 \mathrm{~min}$ is appropriate for the hardness of corn-based diet pellets. Regarding the characteristics of the starch, it is known that starch gelatinization directly influences feed viscosity during the conditioning process and starch digestion in the small intestine (Svihus et al., 2005). Our results showed that increasing the conditioning time of the pelleting process promoted starch gelatinization, which is close to the optimum degree of gelatinization for starch to improve digestion in ruminants (Matsushima, 2006). However, increasing conditioning time of pellets and related increase in starch gelatinization did not change DMI by the calves during this study. Previously, Lesmeister and Heinrichs (2004) demonstrated that thermal treatments of corn (roasted and steam-flaked) compare with conventional processing (grounding and rolling) did not change DMI in calves during the preweaning period.

Despite having a similar intake, we have observed that increasing conditioning time of pelleted starter increased postweaning ADG of calves. This result is inconsistent with the observation of Zhang et al. (2010) who weaned the calves when starter consumption reached $0.7 \mathrm{~kg} / \mathrm{d}$ and $\mathrm{ADG}$ of calves did not change by offering a heat-processed (steam-flaked and extruded corn) starter diet during postweaning. Heat processing has been recognized to increase postruminal energy availability (Lesmeister and Heinrichs, 2004) because of increased intestinal uptake of glucose due to increased starch digestion in the small intestine (Crocker et al., 1998). Therefore, calves receiving starter conditioned for 2 and 4 min may have been more likely to meet their energy requirement for growth from glucose than calves receiving control starter, possibly explaining the differences in ADG. In our study, starters conditioned for 2 and 4 min resulted in higher apparent DM and starch digestibility than the control diet. These findings are in line with Corona et al. (2005) who concluded that thermal treatments such as steam-flaking of corn could increase DM and starch digestibility compared with nonprocessed corn, which might result from the extensive gelatinization and solubility of starch in the rumen and total gastrointestinal tract. Further, Goelema et al. (1999) reported that longer processing time during toasting facilitated water diffusion, and in combination with the processing temperature of $132^{\circ} \mathrm{C}$, resulted in 58\% in gelatinization and enhanced starch digestibility. In our study, greater starch digestibility in calves fed with higher conditioner time than control may be related to greater starch gelatinization and increasing total-tract degradability of starch.

Previously, Lesmeister and Heinrichs (2004) concluded that ruminal ammonia concentration changed by feeding heat-processed starter diets as calves aged. Gimeno et al. (2015) reported a decrease of ammonia concentration in the ruminal content after feeding starch-rich diets and pelleted concentrate. Similarly, a tendency for lower ruminal ammonia concentrations with increasing conditioning time of pellets in our study was observed at postweaning but not at weaning sampling time. Increased microbial use of available $\mathrm{NH}_{3}-\mathrm{N}$ was reported in cattle when steam-flaked corn was replaced with dry rolled corn in the diet (Crocker et al., 1998) and therefore it is plausible to state that increasing conditioning time of pellets might have influenced the use of $\mathrm{NH}_{3}$ by the microbes.

We had hypothesized that increasing conditioning time of the pelleted starter would increase ruminal total VFA concentration; however, we did not observe treatment effects on total VFA concentration and VFA composition. The ruminal VFA concentration in calves is the function of a differential between VFA production (feed fermentation) and VFA absorption into circulation. Greater metabolic activity of ruminal epithelial and increased ruminal absorptive area in calves with their advancing age was attributed to greater $\mathrm{OM}$ fermentation and a greater concentration of VFA in the rumen (Lesmeister and Heinrichs, 2004). However, the lack of influence of conditioning time on ruminal total VFA concentration supports the previous findings of Mojahedi et al. (2018) who reported that the ruminal total VFA concentration was not influenced in calves fed either steam-flaked corn or cracked corn. The lack of an effect of pellet conditioning time on VFA composition in our study was contradictory to the findings of Gelsinger et al. (2019) who explained that starch disappearance was greater for calves fed a high-starch pelleted diet compared with texturized or whole-grain diets. A greater ruminal propionate has also been reported (Lesmeister and Heinrichs, 2004) in dairy calves fed roasted corn versus steam-flaked corn during the postweaning. Lack of an effect of pellet conditioning time on VFA composition in our study compared with others (Lesmeister and Heinrichs, 2004; Gelsinger et al., 2019) could be attributed to the difference in calf age, sampling time and procedures, feed processing techniques, the physical form of starter, and other dietary and management factors (Khan et al., 2016). A limitation of the current study needs to be acknowledged. Given the limited availability of individual housing, the sample size in the present study was restricted to 10 calves per treatment. Further compara- 
tive studies utilizing a larger sample size are necessary to confirm our findings.

Similar concentrations of serum glucose in calves indicate that calves fed different starters did not influence the circulating glucose. The glucose concentration in all calves was lower during postweaning compared with preweaning sampling indicating a shift in energy source from glucose toward VFA. Similar to our findings, a rapid surge in solid feed consumption and reduced blood glucose levels in calves with reduced milk supply was reported by Khan et al. (2007). The concentration of BUN is associated with the protein intake, quality of protein, and development of ruminal fermentation. As calf rumen matures, the BUN concentration increased (Quigley and Bernard, 1992) with advancing age; however, in our study, starter intake and availability of protein from starter feed were the same among calves, which might not have affected the BUN concentration. The key metabolic regulator for growing animals is IGF-1, which encourages nutrient uptake and cellular growth (Vacher et al., 1995; Odle et al., 1996). In addition, it may increase the development of the neonatal digestive system and may affect or interact with several other growth factors (Vacher et al., 1995). As BW gain increases, the plasma concentration of IGF-1 also increases (Smith and Sheffield, 2002); however, the IGF-1 concentration did not differ among treatments in the present study.

\section{CONCLUSIONS}

The conditioning time during the pelleting process of starter feed increased the gelatinization of starch, durability, and hardness of the pellets but did not influence intake, feed efficiency, and skeletal growth during the first $70 \mathrm{~d}$ of age. Increasing conditioning retention time from 0 to 4 min improved only postweaning ADG; however, the final BW was similar among treatments. We observed lower ruminal ammonia concentration when calves fed the pelleted diets conditioned at 2 and $4 \mathrm{~min}$ compared with control. In general, increasing pelleting conditioner retention time increased the digestibility of DM and starch around weaning, but its effect on the growth performance of calves may be marginal. However, this trial was limited by a small sample size $(\mathrm{n}=$ 10 per treatment); therefore, differences in the growth performance of calves might be more detectable with a larger number of treatment replicates.

\section{ACKNOWLEDGMENTS}

The authors acknowledge the Department of Animal Science of the Ferdowsi University of Mashhad (Iran) for their cooperation. The authors are grateful to Dordaneh Razavi Animal and Poultry Feed Co. (Mashhad) and Fereydoon Bagheri for their technical and financial support of this project. The authors confirm that there are no recognized conflicts of interest associated with this publication and there has been no financial support for this work that could have influenced its outcome.

\section{REFERENCES}

AACC International. 1999. Method 76-13.01: Total starch assay procedure (Megazyme amyloglucosidase/alpha-amylase method). Approved Methods of Analysis. 11th ed. Approved Nov. 3, 1999. AACC Int., St. Paul, MN. https://doi.org/10.1094/ AACCIntMethod-76-13.01.

AACC International. 2014. Method 76-31.01. Determination of damaged starch spectrophotometric method. Approved Methods of Analysis. https://doi.org/10.1094/AACCIntMethod-76-33.01.

Abdelsamei, A. H., D. G. Fox, L. O. Tedeschi, M. L. Thonney, D. J. Ketchen, and J. R. Stouffer. 2005. The effect of milk intake on forage intake and growth of nursing calves. J. Anim. Sci. 83:940-947. https://doi.org/10.2527/2005.834940x.

Abdollahi, M. R., V. Ravindran, T. J. Wester, G. Ravindran, and D. V. Thomas. 2012. Effect of improved pellet quality from the addition of a pellet binder and/or moisture to a wheat based diet conditioned at two different temperatures on performance, apparent metabolisable energy and ileal digestibility of starch and nitrogen in broilers. Anim. Feed Sci. Technol. 175:150-157. https://doi.org/ 10.1016/j.anifeedsci.2012.05.001.

American Society of Agricultural Engineers (ASAE). 1983. Method of determining and expressing fineness of feed materials by sieving ASAE standards. Agricultural Engineers Yearbook of Standards. ASAE, St. Joseph, MI.

AOAC. 1990. Official Methods of Analysis, 15th ed. Association of Official Analytical Chemists, Arlington, VA.

Aragona, K. M., F. X. Suarez-Mena, T. S. Dennis, J. D. Quigley, W. Hu, T. M. Hill, and R. L. Schlotterbeck. 2020. Effect of starter form, starch concentration, and amount of forage fed on Holstein calf growth from 2 to 4 months of age. J. Dairy Sci. 103:2324-2332. https://doi.org/10.3168/jds.2019-17474.

Bach, A., A. Gimenez, J. L. Juaristi, and J. Ahedo. 2007. Effects of physical form of a starter for dairy replacement calves on feed intake and performance. J. Dairy Sci. 90:3028-3033. https://doi .org/10.3168/jds.2006-761.

Bal, M. A., R. D. Shaver, A. G. Jirovec, K. J. Shinners, and J. G. Coors. 2000. Crop processing and chop length of corn silage: Effects on intake, digestion, and milk production by dairy cows. J. Dairy Sci. 83:1264-1273. https://doi.org/10.3168/jds .S0022-0302(00)74993-9.

Bateman, H. G. II, T. M. Hill, J. M. Aldrich, and R. L. Schlotterbeck. 2009. Effects of corn processing, particle size, and diet form on performance of calves in bedded pens. J. Dairy Sci. 92:782-789. https://doi.org/10.3168/jds.2008-1242.

Berends, H., M. Vidal, M. Terre, L. N. Leal, J. Martin-Tereso, and A. Bach. 2018. Effects of fat inclusion in starter feeds for dairy calves by mixing increasing levels of a high-fat extruded pellet with a conventional highly fermentable pellet. J. Dairy Sci. 101:1096210972. https://doi.org/10.3168/jds.2018-15116.

Corona, L., S. Rodriguez, R. A. Ware, and R. A. Zinn. 2005. Comparative effects of whole, ground, dry-rolled, and steam-flaked corn on digestion and growth performance in feedlot cattle. Prof. Anim. Sci. 21:200-206. https://doi.org/10.15232/S1080-7446(15)31203-1.

Crochet, P., T. Beauxis-Lagrave, T. R. Noel, R. Parker, and S. G. Ring. 2005. Starch crystal solubility and starch granule gelatinisation. Carbohydr. Res. 340:107-113. https://doi.org/10.1016/j .carres.2004.11.006.

Crocker, L. M., E. J. DePeters, J. G. Fadel, H. Perez-Monti, S. J. Taylor, J. A. Wyckoff, and R. A. Zinn. 1998. Influence of processed 
corn grain in diets of dairy cows on digestion of nutrients and milk composition. J. Dairy Sci. 81:2394-2407. https://doi.org/10.3168/ jds.S0022-0302(98)70131-6.

DeVries, T. J., and M. A. G. von Keyserlingk. 2009. Feeding method affects the feeding behavior of growing dairy heifers. J. Dairy Sci. 92:1161-1168. https://doi.org/10.3168/jds.2008-1314.

Fahrenholz, A. C. 2015. Evaluating factors affecting pellet durability and energy consumption in a pilot feed mill and comparing methods for evaluating pellet durability. $\mathrm{PhD}$ thesis, Department of Grain Science and Industry College of Agriculture, Kansas State University, Manhattan, KS.

Firkins, J. L., M. L. Eastridge, N. R. St-Pierre, and S. M. Noftsger. 2001. Effects of grain variability and processing on starch utilization by lactating dairy cattle. J. Anim. Sci. 79(E. Suppl.):E218E238.

Gelsinger, S. L., W. K. Coblentz, G. I. Zanton, R. K. Ogden, and M. S. Akins. 2019. Ruminal in situ disappearance and whole-tract digestion of starter feeds in calves before, during, and after weaning. J. Dairy Sci. 102:2196-2206. https://doi.org/10.3168/jds.2018-15551.

Gimeno, A., A. Al Alami, P. G. Toral, P. Frutos, L. Abecia, M. Fondevila, and C. Castillo. 2015. Effect of grinding or pelleting high grain maize-or barley-based concentrates on rumen environment and microbiota of beef cattle. Anim. Feed Sci. Technol. 203:67-78. https://doi.org/10.1016/j.anifeedsci.2015.03.003.

Goelema, J. O., A. Smits, L. M. Vaessen, and A. Wemmers. 1999. Effects of pressure toasting, expander treatment and pelleting on in vitro and in situ parameters of protein and starch in a mixture of broken peas, lupins and faba beans. Anim. Feed Sci. Technol. 78:109-126. https://doi.org/10.1016/S0377-8401(98)00266-1.

Gressley, T. F., M. B. Hall, and L. E. Armentano. 2011. Ruminant Nutrition Symposium: Productivity, digestion, and health responses to hindgut acidosis in ruminants. J. Anim. Sci. 89:1120-1130. https://doi.org/10.2527/jas.2010-3460.

Hadam, D., J. Kanski, K. Burakowska, G. B. Penner, Z. M. Kowalski, and P. Gorka. 2016. Short communication: Effect of canola meal use as a protein source in a starter mixture on feeding behavior and performance of calves during the weaning transition. J. Dairy Sci. 99:1247-1252. https://doi.org/10.3168/jds.2015-10399.

Hintze, J. 2008. PASS 2008. NCSS, LLC, Kaysville, UT.

Hu, W., T. M. Hill, T. S. Dennis, F. X. Suarez-Mena, J. D. Quigley, J. R. Knapp, and R. L. Schlotterbeck. 2018. Relationships between starch concentration of dry feed, diet digestibility, and growth of dairy calves up to 16 weeks of age. J. Dairy Sci. 101:7073-7081. https://doi.org/10.3168/jds.2018-14583.

Huntington, G. B. 1997. Starch utilization by ruminants: From basics to the bunk. J. Anim. Sci. 75:852-867. https://doi.org/10.2527/ 1997.753852x.

Iranian Council of Animal Care. 1995. Guide to the Care and Use of Experimental Animals. Vol. 1. Ferdowsi University of Mashhad, Mashhad, Iran.

Jarrah, A., G. R. Ghorbani, P. Rezamand, and M. Khorvash. 2013. Short communication: Effects of processing methods of barley grain in starter diets on feed intake and performance of dairy calves. J. Dairy Sci. 96:7269-7273. https://doi.org/10.3168/jds.2013-6645.

Kertz, A. F., and H. Chester-Jones. 2004. Invited review: Guidelines for measuring and reporting calf and heifer experimental data. J. Dairy Sci. 87:3577-3580. https://doi.org/10.3168/jds.S0022 $-0302(04) 73495-5$.

Khafipour, E., D. O. Krause, and J. C. Plaizier. 2009. A grain-based subacute ruminal acidosis challenge causes translocation of lipopolysaccharide and triggers inflammation. J. Dairy Sci. 92:10601070. https://doi.org/10.3168/jds.2008-1389.

Khan, M. A., A. Bach, D. M. Weary, and M. A. G. von Keyserlingk. 2016. Invited review: Transitioning from milk to solid feed in dairy heifers. J. Dairy Sci. 99:885-902. https://doi.org/10.3168/jds.2015 $-9975$.

Khan, M. A., H. J. Lee, W. S. Lee, H. S. Kim, S. B. Kim, K. S. Ki, S. J. Park, J. K. Ha, and Y. J. Choi. 2007. Starch source evaluation in calf starter: I. Feed consumption, body weight gain, structural growth, and blood metabolites in Holstein calves. J. Dairy Sci. 90:5259-5268. https://doi.org/10.3168/jds.2007-0338.
Khan, M. A., H. J. Lee, W. S. Lee, H. S. Kim, S. B. Kim, S. B. Park, K. S. Baek, J. K. Ha, and Y. J. Choi. 2008. Starch source evaluation in calf starter: II. Ruminal parameters, rumen development, nutrient digestibilities, and nitrogen utilization in Holstein calves. J. Dairy Sci. 91:1140-1149. https://doi.org/10.3168/jds.2007-0337.

Laarman, A. H., T. Sugino, and M. Oba. 2012. Effects of starch content of calf starter on growth and rumen $\mathrm{pH}$ in Holstein calves during the weaning transition. J. Dairy Sci. 95:4478-4487. https:/ /doi.org/10.3168/jds.2011-4822.

Lesmeister, K. E., and A. J. Heinrichs. 2004. Effects of corn processing on growth characteristics, rumen development, and rumen parameters in neonatal dairy calves. J. Dairy Sci. 87:3439-3450. https:// doi.org/10.3168/jds.S0022-0302(04)73479-7.

Matsushima, J. K. 2006. History of feed processing. Pages 1-16 in Proc. of Cattle Grain Processing Symposium. Oklahoma State University, Stillwater.

Miller-Cushon, E. K., and T. J. DeVries. 2011. Effect of early feed type exposure on diet-selection behavior of dairy calves. J. Dairy Sci 94:342-350. https://doi.org/10.3168/jds.2010-3382.

Mirzaei, M., M. Khorvash, G. R. Ghorbani, M. Kazemi-Bonchenari, A. Riasi, A. Soltani, B. Moshiri, and M. H. Ghaffari. 2016. Interactions between the physical form of starter (mashed versus textured) and corn silage provision on performance, rumen fermentation, and structural growth of Holstein calves. J. Anim. Sci 94:678-686. https://doi.org/10.2527/jas.2015-9670.

Moeinoddini, H. R., M. Alikhani, F. Ahmadi, G. R. Ghorbani, and P. Rezamand. 2017. Partial replacement of triticale for corn grain in starter diet and its effects on performance, structural growth and blood metabolites of Holstein calves. Animal 11:61-67. https://doi .org/10.1017/S1751731116001233.

Mojahedi, S., M. Khorvash, G. R. Ghorbani, E. Ghasemi, M. Mirzaei, and F. Hashemzadeh-Cigari. 2018. Performance, nutritional behavior, and metabolic responses of calves supplemented with forage depend on starch fermentability. J. Dairy Sci. 101:7061-7072. https://doi.org/10.3168/jds.2017-13798.

Morris, T. R. 1999. Experimental Design and Analysis in Animal Sciences. CABI Publishing, New York, NY.

NRC. 2001. Nutrient Requirement of Dairy Cattle. 7th rev. ed. Natl. Acad. Sci., Washington, DC.

Odle, J., R. T. Zijlstra, and S. M. Donovan. 1996. Intestinal effects of milkborne growth factors in neonates of agricultural importance. J. Anim. Sci. 74:2509-2522. https://doi.org/10.2527/1996 $.74102509 x$.

Omidi-Mirzaei, H., A. Azarfar, A. Kiani, M. Mirzaei, and M. H. Ghaffari. 2018. Interaction between the physical forms of starter and forage source on growth performance and blood metabolites of Holstein dairy calves. J. Dairy Sci. 101:6074-6084. https://doi .org/10.3168/jds.2017-13892.

Pazoki, A., G. R. Ghorbani, S. Kargar, A. Sadeghi-Sefidmazgi, J. K. Drackley, and M. H. Ghaffari. 2017. Growth performance, nutrient digestibility, ruminal fermentation, and rumen development of calves during transition from liquid to solid feed: Effects of physical form of starter feed and forage provision. Anim. Feed Sci. Technol. 234:173-185. https://doi.org/10.1016/j.anifeedsci.2017 .06 .004 .

Pezhveh, N., G. R. Ghorbani, P. Rezamand, and M. Khorvash. 2014. Effects of different physical forms of wheat grain in corn-based starter on performance of young Holstein dairy calves. J. Dairy Sci. 97:6382-6390. https://doi.org/10.3168/jds.2013-7718.

Philippeau, C., C. Martin, and B. Michalet-Doreau. 1999. Influence of grain source on ruminal characteristics and rate, site, and extent of digestion in beef steers. J. Anim. Sci. 77:1587-1596. https://doi .org/10.2527/1999.7761587x.

Porter, J. C., R. G. Warner, and A. F. Kertz. 2007. Effect of fiber level and physical form of starter on growth and development of dairy calves fed no forage. The Prof. Anim. Sci. 23:395-400. https://doi .org/10.15232/S1080-7446(15)30994-3.

Quigley, J. D. III, and J. K. Bernard. 1992. Effects of nutrient source and time of feeding on changes in blood metabolites in young calves. J. Anim. Sci. 70:1543-1549. https://doi.org/10.2527/1992 $.7051543 x$. 
Senevirathne, N. D., J. L. Anderson, W. R. Gibbons, and J. A. Clapper. 2017. Growth performance of calves fed microbially enhanced soy protein in pelleted starters. J. Dairy Sci. 100:199-212. https:/ /doi.org/10.3168/jds.2016-11221.

Smith, J. L., and L. G. Sheffield. 2002. Production and regulation of leptin in bovine mammary epithelial cells. Domest. Anim. Endocrinol. 22:145-154. https://doi.org/10.1016/S0739-7240(02)00121 -2 .

Svihus, B., K. H. Klovstad, V. Perez, O. Zimonja, S. Sahlstrom, R. B. Schuller, W. K. Jeksrud, and E. Prestlokken. 2004. Physical and nutritional effects of pelleting of broiler chicken diets made from wheat ground to different coarsenesses by the use of roller mill and hammer mill. Anim. Feed Sci. Technol. 117:281-293. https://doi .org/10.1016/j.anifeedsci.2004.08.009.

Svihus, B., A. K. Uhlen, and O. M. Harstad. 2005. Effect of starch granule structure, associated components, and processing on nutritive value of cereal starch: A review. Anim. Feed Sci. Technol. 122:303-320. https://doi.org/10.1016/j.anifeedsci.2005.02.025.

Vacher, P. Y., G. Bestetti, and J. W. Blum. 1995. Insulin-like growth factor I absorption in the jejunum of neonatal calves. Biol. Neonate 68:354-367. https://doi.org/10.1159/000244256.
Van Keulen, J., and B. A. Young. 1977. Evaluation of acid-insoluble ash as a natural marker in ruminant digestibility studies. J. Anim. Sci. 44:282-287. https://doi.org/10.2527/jas1977.442282x.

Van Soest, P. J., J. B. Robertson, and B. A. Lewis. 1991. Methods for dietary fiber, neutral detergent fiber nonstarch polysaccharide in relation to animal nutrition. J. Dairy Sci. 74:3583-3597. https:// doi.org/10.3168/jds.S0022-0302(91)78551-2.

Vicari, T., J. J. van den Borne, W. J. Gerrits, Y. Zbinden, and J. W. Blum. 2008. Postprandial blood hormone and metabolite concentrations influenced by feeding frequency and feeding level in veal calves. Domest. Anim. Endocrinol. 34:74-88. https://doi.org/10 .1016/j.domaniend.2006.11.002.

Waigh, T. A., M. J. Gidley, B. U. Komanshek, and A. M. Donald. 2000. The phase transformations in starch during gelatinisation: A liquid crystalline approach. Carbohydr. Res. 328:165-176. https:// doi.org/10.1016/S0008-6215(00)00098-7.

Zhang, Y. Q., D. C. He, and Q. X. Meng. 2010. Effect of a mixture of steam-flaked corn and soybeans on health, growth, and selected blood metabolism of Holstein calves. J. Dairy Sci. 93:2271-2279. https://doi.org/10.3168/jds.2009-2522. 